THE TYNDALE OLD TESTAMENT LECTURE, 1977*

\title{
ESCHATOLOGY IN CHRONICLES
}

By H. G. M. WILLIAMSON

\section{Introduction}

The title of this lecture requires a rather careful explanation of both its main elements. The word "eschatology" has been deliberately chosen because of its appearance in the title of an influential book by O. Plöger, translated into English as Theocracy and Eschatology. ${ }^{1}$ Stated very briefly, Plöger's thesis is that in the post-exilic community centred on Jerusalem there arose during the Persian and Hellenistic periods a sharp tension in which "the various attitudes to the eschatological question may be regarded as the decisive point of difference" (p.46). On the one hand, Plöger finds evidence in a number of texts, principally Isaiah 24-7, Zechariah 12-14 and Joel, for a strongly eschatological faith which over the years developed the hopes of the earlier restoration prophecies into the apocalyptic expectations of the Hasidim of Maccabean times, expressed particularly in the book of Daniel. Quite opposed to these groups stood a theocratic party whose adherents believed that the purposes of God were realized in the present community to such an extent that there was little if any place for eschatological expectation. In seeking to establish his case, Plogger argues that "the noneschatological view of the Chronicler ... represents the official line within the theocracy" (p. 111).

In Old Testament scholarship, "eschatology" is used in a

* Delivered at Tyndale House, Cambridge, 15th July, 1977.

' Blackwell, Oxford (1968), translated by S. Rudman from the second edition of Theokratie und Eschatologie (WMANT 2) Neukirchener Verlag, Neukirchen (1962). 
wide variety of ways, ${ }^{2}$ so much so that some even try to avoid it altogether. As it is by no means my intention to add to this confusion, let it here be stressed that our title means to imply no more than to ask how far Plöger's categorization is justified.

By "Chronicles", I mean just that. For most scholars (Plöger included; cf. p. 37), the work of the Chronicler is thought to include either the whole or a substantial part of Ezra and Nehemiah. ${ }^{3}$ I do not share this view, for reasons which I have set out elsewhere. ${ }^{4}$ If I am mistaken in this view, then that ought not to affect the present study, for we would expect the conclusions which emerge from the major part of a writer's work at least not to contradict his viewpoint as a whole. At the same time, however, it seems worthwhile to take as a working hypothesis the view that 1 and 2 Chronicles constitute a separate work, for only then are we likely to make a serious attempt to establish their approach to any given topic and hence to have a firmer basis on which finally to assess the strengths and weaknesses of the hypothesis itself.

It is, then, our intention to examine the quite widespread contemporary understanding of one aspect of the Chronicler's theology that is typified by Plöger's work. What appears at first sight to be the study of a rather detailed point concerning a somewhat neglected book of the Old Testament may be justified on at least three grounds. First, it is agreed that this view of Chronicles differentiates it from the mainstream of Old Testament thought, setting it at the very edge of the Canon, ${ }^{5}$ which so far as the Old Testament is concerned is usually thought to be characterized by an

\footnotetext{
${ }^{2}$ For a recent, clear statement of this variety, see J. Bright, Covenant and Promise SĊM Press, London (1977) 18-19.

${ }^{3}$ In recent years, a number have adopted the position maintained by K.-F. Pohlmann, Studien zum dritten Esra. Ein Beitrag zur Frage nach dem ursprünglichen Schluss des chronistischen Geschichtswerkes (FRLANT 104) Vandenhoeck \& Ruprecht, Göttingen (1970), who argues, mainly on the basis of I Esdras, that the Chronicler's work originally concluded with Ezr. 1-10 and Ne. 8.

${ }^{4}$ Israel in the Books of Chronicles The University Press, Cambridge (1977) 5-70. On p.3, I observed in passing that the question of the extent of the Chronicler's work might have implications for the usual assessment of his understanding of eschatology, messianism and theocracy. The present lecture may be seen as an attempt to justify this suggestion.

${ }^{5}$ W. Rudolph, Chronikbücher (HAT 21) J. C. B. Mohr, Tübingen (1955) xxiii.
} 
openness to the future of whatever sort. ${ }^{6}$ Such a concession should not be made without first subjecting it to the most rigorous scrutiny. Secondly, in Plöger's view, Chronicles plays an important role in reconstructing one side of the divisions which are to be seen in the post-exilic period. Though this period is often shrouded in obscurity, it was a vital one both for the development of the Jewish people, and, hence, of their Bible in the form in which we have it today. Thirdly, the groups and parties with which we are more familiar from the background of the New Testament will have started to take shape at this time. ${ }^{7}$ To the elucidation of this important topic too, our study may be seen as a small contribution.

\section{The Present Position}

We must start, then, by setting out in rather more detail Plöger's understanding of the Chronicler's view of theocracy. First, he draws on von Rad's conclusion that just as in Ezra and Nehemiah the term Israel is used for the tribes of Judah and Benjamin which made up the bulk of the post-exilic community, so too in the history of the divided monarchy the name could only properly be used for those who still adhered to the house of David (p. 37) ${ }^{8}$ This emphasis on David, which leads to the centrality of Jerusalem and the temple in the theocracy, was in part derived from the Deuteronomic history, but Plöger follows Noth ${ }^{9}$ and Galling ${ }^{10}$ in arguing that it received added significance in the Chronicler's day because of the controversy with the Samaritans. They, of course,

\footnotetext{
- See D. L. Baker, Two Testaments, One Bible Inter-Varsity Press, Leicester (1976), for a full survey with abundant bibliography.

${ }^{7}$ Note how many books on the background to the New Testament start their survey with the Persian period; e.g. F. F. Bruce, New Testament History Nelson, London (1969); E. Lohse, Umwelt des neuen Testaments Vandenhoeck \& Ruprecht, Göttingen (1971) E. T., The New Testament Environment SCM Press, London (1976); R. H. Pfeiffer, History of New Testament Times A. and C. Black, London (1949); B. Reicke, Neutestamentliche Zeitgeschichte Alfred Töpelmann, Berlin (1964) E.T., The New Testament Era A. and C. Black, London (1968).

${ }^{8}$ See G. von Rad, Das Geschichtsbild des chronistischen Werkes (BWANT IV/3) Kohlhammer, Stuttgart (1930) 18-37.

${ }^{9}$ M. Noth, Überlieferungsgeschichtliche Studien 1 Max Niemeyer, Halle (1943) 171-80.

${ }^{10} \mathrm{~K}$. Galling, Die Bücher der Chronik, Esra, Nehemia (ATD 12) Vandenhoeck \& Ruprecht, Göttingen (1954) $14 f$.
} 
shared the same views on the earlier period of Israelite history, but the Chronicler drew a sharp distinction between the respective communities by tracing the history of the people of God down through the period of the monarchy centred on Jerusalem and showing its continuity with the theocracy re-established under Ezra and Nehemiah (p. 39). This brings us to the heart of Plöger's exposition, for which he is explicitly indebted to W. Rudolph, ${ }^{11}$ for he sees this realization of the theocracy as "influenced not only by an outward looking anti-Samaritan aim, but also by an inward looking anti-eschatological point of view" (p. 40). According to Rudolph, the Chronicler's purpose was "to present the realisation of theocracy in Israel" (p. 404). The twin pillars of this theocracy were the Davidic dynasty and the Jerusalem temple. However, hardly any messianic expectation is to be found, so it is unlikely that the Davidic dynasty had abiding significance for the Chronicler. On the other hand, he says:

we must not overlook the fact that in the second part of his presentation, the Books of Ezra and Nehemiah, he is pursuing the aim of describing the founding of the new people of God as it should be in accordance with the will of God - a community gathered around its Temple in zealous worship, protected by secure walls, in obedience to the divine Law, and inwardly separated from everything alien. This means that the actual Jewish community, especially as it is presented in Neh. xii 44-xiii 3, so fully realised the idea of theocracy for the Chronicler that there was no need of any further eschatological hope. The failure of the Davidic dynasty could be borne, so long as the second pillar of the theocracy, the Jerusalem Temple, stood firm. God had made this possible by moving the hearts of the Persian kings. The significance of the house of David for salvation was then limited to the fact that David and Solomon had created for the Temple those ordinances upon which the acceptable worship of the present community depended (p. 408f.).

"W. Rudolph, Chronikbücher. Parts of the introduction to this commentary, including the sections on which Plöger drew, were translated into English by P. R. Ackroyd and read by Rudolph at a meeting of the Society for Old Testament Study in Edinburgh, July, 1954. They were subsequently published under the title "Problems of the Books of Chronicles" in VT 4 (1954) 401-9. English citations here are from this article. 
In taking up this exposition, Plöger links it with his understanding of the Priestly Writing's view of history, namely that after the establishment of the cultic community on Mount Sinai, "there was no prospect of fundamental change" (p. 40).

As already mentioned, Plöger's whole thesis has had a very considerable influence on current understanding of the development of the theology of the post-exilic community, and although the recent major work of P. D. Hanson, The Dawn of Apocalyptic, Fortress Press, Philadelphia (1975), expresses reservations about some of Plöger's analysis, particularly his association of the opposing viewpoints with parties and sects, yet its own presentation of a struggle between a "visionary" element on the one hand and a "realistic" or "pragmatic" element on the other, based upon their respective sociological status, is in a number of respects close to Plöger's view as far as the early post-exilic period is concerned, 12 for this latter element is defined as "the hierocratic party dominated by the Zadokite priests which controlled the high priesthood" (p. 210). Hanson's analysis of the development of this struggle is far more detailed and subtle than Plöger's, so that he finds in the work of the Chronicler a more conciliatory position of the (at that time) victorious hierocratic party after the very exclusive claims of what he sees as a Zadokite revision of the book of Ezekiel. Nevertheless, the Chronicler's history remains a product of the hierocratic party, one of whose main emphases, ${ }^{13}$ which would have alienated it from the visionary group, was its "absence of an eschatological dimension" (p. 276). Hanson concludes that there is a marked interest in David and his establishment of the temple cult, but

\footnotetext{
${ }^{12}$ It is only fair to point out that Hanson sees a change in the later period when he argues: "The untenability of the 'party' theory for the origins of apocalyptic becomes clear when one then moves on to consider developments in the second century, and finds Zadokites, themselves supplanted as temple priests, belonging to the apocalyptically orientated community of Qumran"'(p. 20). Nevertheless, one would have welcomed more interaction with Plöger in Hanson's book.

${ }^{13}$ The other is the Chronicler's pro-Persian proclivity. However, as all the evidence for this is drawn from Ezra-Nehemiah (pp. 274-5), it need not be treated here. It should be noted in this connection that in our view, the last two verses of the present books of Chronicles were not part of the original composition, but were added subsequently from Ezr. 1; see Israel in the Books of Chronicles 7-10.
} 
the eschatological element implicit in the Davidic covenant is neglected ... The fulfillment of history is not envisioned in an event of the future which would supersede and even negate past history, but is recognized in the present order (pp. 276f.).

Again

The Chronicler, living at a time when the temple was erected and standing at the very center of the life of the community, sees in the present order the fulfillment of history; past history is used not to point beyond the present to a future fulfillment, but to prove that the present represents the culmination toward which past history has been moving (p. 277).

\section{Alternative viewpoints: survey and critique}

In modern studies of Chronicles, two approaches have been adopted which present an alternative viewpoint to that just outlined. The first, adumbrated in a brief, but suggestive, study of D. N. Freedman ${ }^{14}$ some while ago, has recently been developed independently by F. M. Cross ${ }^{15}$ and J. D.

Newsome. ${ }^{16}$ Although in certain important points of detail there are differences between these scholars' positions, they do all agree that the most plausible setting for Chronicles is the post-exilic restoration of the temple under the leadership of Zerubbabel and Joshua the high priest. Its ideology is close to that of Haggai and Zechariah 1-8, and may have been the historical expression of the movement with which they were associated.

This understanding of the Chronicler is in marked contrast to that of Plöger. It makes of him one who shared in the hopes for the restoration of the Davidic dynasty in the person of Zerubbabel and for whom the future was wide open. There is certainly no question of an acquiescence in the present order of things, but rather an encouragement to faith in a new work which God is about to initiate. Furthermore, there is a certain attractiveness to this view in that it suggests a specific reason

14 "The Chronicler's Purpose" CBQ 23 (1961) 436-42.

15 "A Reconstruction of the Judean Restoration" JBL 94 (1975) 4-18.

16 "Toward a New Understanding of the Chronicler and his Purposes", JBL 94 (1975) 201-17, reproducing, for the most part, the conclusions of his unpublished doctoral thesis, The Chronicler's View of Prophecy Vanderbilt University (1973). 
for the composition of Chronicles, and because it clearly was a period in which what Newsome calls the "cluster of concerns" (p. 215) for kingdom, prophecy and cult, all prominent in Chronicles, are known to have converged.

However, our knowledge of the history of Judah in the Persian period is so episodic that we have to be aware of the temptation to bunch together around such fixed points as we do have all those unknown quantities which might in reality have filled one or another of the many gaps. In the present case, it may be argued first that evidence for a date for Chronicles substantially later than the last quarter of the sixth century $\mathrm{BC}^{17}$ is dismissed too casually by these scholars, and secondly that the superficial attractiveness of their solution conceals difficulties to which they have not done justice.

The dating of Chronicles is a matter of the greatest delicacy; the more one investigates the evidence and usual arguments advanced, the more uncertain it all becomes. What is clear, however, is that if $1 \mathrm{Ch} .3: 19-21$ is part of the original composition, then it cannot date from earlier than the second generation after Zerubbabel. ${ }^{18}$ It is thus not surprising to find that Freedman, Cross and Newsome all deny that the genealogies of $1 \mathrm{Ch} .1-9$ were an original part of the Chronicler's work. It must be observed, however, that their only argument for this position is that the genealogies contradict their dating. ${ }^{19}$ This at once raises suspicion, and it is increased by the fact that neither Cross nor Newsome (whose articles are quite recent) makes any attempt to deal with such studies as have tried to show that in fact $1 \mathrm{Ch} .1-9$ is both

\footnotetext{
${ }^{17}$ It should be observed that this revival of an early date for Chronicles is based on grounds quite separate from those previously advocated by A. C. Welch in PostExilic Judaism, Blackwood, Edinburgh and London (1935), 241f., and The Work of the Chronicler: its Purpose and Date (The Schweich Lectures, 1938), The University Press, Oxford (1939), and that the one approach cannot appeal to the other for support. In fact, Welch's conclusions in this particular were based on a literary division of the text of Chronicles which would find few, if any, adherents today, despite the perspicacity of many other aspects of his presentation.

${ }^{18}$ There is little agreement over how to construe $v v .21 b-24$, as the commentaries show. It may take the genealogy further, but as this is not agreed by all (see R. K. Harrison, Introduction to the Old Testament, Tyndale Press, London (1970) 1155), it has seemed safest to stop here at the point on which all do agree, and which is sufficient for our present purposes.

${ }^{19}$ Welch, Post-Exilic Judaism 185f., did at least suggest reasons for his relegation of these chapters to a secondary status. However, his main arguments, namely that they lack unity and do not fit with the themes of the rest of Chronicles, have been refuted by more recent studies; see the next note.
} 
consistent with the thought and style of the remainder of the book, and that it contributes to its overall presentation. ${ }^{20}$ It could never be proved, of course, that a later editor has not added a few generations to the Davidic genealogy in order to bring it down to his own day, but many theories of far reaching addition to an original genealogical core ${ }^{21}$ have been shown to be less than securely based, ${ }^{22}$ and in the case of the Davidic genealogy in particular, Johnson has demonstrated (pp. 69-71) that its structure conforms to that which the Chronicler uses elsewhere. Finally, from a literary point of view, there is no break at all in the genealogy as far as Zerubbabel's grandchildren (verse 21a), but thereafter in the text as we now have it (and it must be admitted that it is not above suspicion) there is a break, ${ }^{23}$ "the sons of Rephaiah" etc. being loosely attached without the copula. Thus, if we are going to look for editorial additions, this is the most likely place; but, as indicated above, it is already substantially after the period of Zerubbabel.

A related point concerning Cross's more elaborate theory of three successive editions of Chronicles should be mentioned here. $\mathrm{Chr}_{3}$ is his name for the final edition, dated $c$. $400 \mathrm{BC}$ and comprising the whole of our Chronicles-EzraNehemiah. Cross then uses the evidence of 1 Esdras and Josephus to argue for a $\mathrm{Chr}_{2} c .450 \mathrm{BC}$. Its ending will accordingly have consisted of (approximately) Ezra with Ne. 8. Cross also argues, however, that "the two editions differ at the beginning, $\mathrm{Chr}_{3}$ introducing the genealogies of 1 Chronicles 1-9" (p. 11). For this assertion there is no evidence. 1 Esdras $^{24}$ and Josephus, of course, cannot help us

${ }^{20} \mathrm{M}$. D. Johnson, The Purpose of the Biblical Genealogies (SNTSMS 8) The University Press, Cambridge (1969) 44-76; S. Japhet, The Ideology of the Book of

Chronicles and its Place in Biblical Thought (Hebrew), Doctoral Thesis, The Hebrew University, Jerusalem (1973) 283-90.

${ }^{21}$ See principally M. Noth, Überlieferungsgeschichtliche Studien $1117-22$, and W. Rudolph, Chronikbücher, ad loc.

${ }^{22}$ Israel in the Books of Chronicles 72-82.

${ }^{23}$ See C. F. Keil, Biblischer Commentar über die nachexilischen Geschichtsbücher: Chronik, Esra, Nehemia und Esther Dörffling \& Franke, Leipzig (1870) 58.

${ }^{24} 1 \mathrm{Esdras}$ in its present form starts at $2 \mathrm{Ch}$. 35 . However, the work is almost certainly only the fragment of an originally more extensive compilation; see Pohlmann, Studien zum dritten Esra. We have no proof of its original opening, however, although I have argued against Pohlmann that it is unlikely to have been co-extensive with the whole of Chronicles; see Israel in the Books of Chronicles 14-21. 
here, and, as Cross concedes, the Davidic line is traced in Ezra 8:3 as far as Hattush, who is already in what we have suggested might be the additional material at 1 Chronicles 3:22. Thus, even if we were to concede for the sake of this particular discussion that 1 Esdras could be used to reconstruct an earlier stage of the growth of Chronicles, that still would not necessarily involve the exclusion of 1 Chronicles $1-9$. We may then observe finally that for Cross's postulated $\mathrm{Chr}_{1}$ (1 Ch. 10-Ezr. 3:13) there is no additional evidence beyond that already suggested by Freedman. The Greek versions and Josephus can certainly be adduced to open discussion of the postulated $\mathrm{Chr}_{2}$ and 3 , but we should not be misled into thinking that any new evidence has thereby been advanced to support an even earlier $\mathrm{Chr}_{1}$.

A further difficulty for Cross and Freedman (though not for Newsome, since he separates the whole of Ezra from Chronicles) is raised by Ezra 4, which includes references, out of their strict chronological place, as late as Artaxerxes, who ascended the throne only in 465 B.C. Thus Freedman guesses that an original narrative about Zerubbabel and the temple has been supplanted by the Aramaic record now found in Ezra 4:6-6:18, while Cross simply has his $\mathrm{Chr}_{1}$ end at Ezra $3: 13$. This is not the place for an examination of the intricate problems surrounding the composition of Ezra 1-6, but no view that has to speculate to this extent without any external evidence against the present form of the text can be wholly self-authenticating.

Finally, on the issue of dating, we must not overlook the probable reference to Darics in 1 Chronicles 29:7. Two points are at issue here that need to be settled before the reference can be used with any confidence for dating purposes. The first seems now to command widespread agreement, namely that Darius I was the first to mint Darics, and that only some years after his accession. It used to be objected to this view that this would leave an awkward gap between the conquest by Cyrus of Croesus of Lydia, whence the Persians derived their own coinage. ${ }^{25}$ It is now apparent, however, that in fact the

\footnotetext{
${ }^{25}$ So, popularly, P. Gardner, A History of Ancient Coinage, 700-300 BC Clarendon, Oxford (1918) 87-8.
} 
Persians at first simply continued to mint Croeseids, ${ }^{26}$ and indeed Greek coins in both silver and gold were found in the foundation deposit of Darius' own throne room at Persepolis. ${ }^{27}$ The evidence thus points strongly to a later date for the introduction of Darics, $515 \mathrm{BC}$ at the earliest.

Secondly, however, can we be sure that it is to Darics that 1 Chronicles 29:7 refers? (a) No word for Daric is known in Old Persian. ${ }^{*}$ darika- has been suggested ${ }^{28}$ and is etymologically possible, ${ }^{29}$ but remains unattested. What does now seem likely, however, is that this is not an abbreviation of the superficially similar word for gold, daraniy $a-{ }^{30}$ which some have then suggested was used for coins throughout the period of the Persian empire. Furthermore, such an abbreviation would in any case leave the silver Darics unexplained, ${ }^{31}$ and would not of itself prove that the Daric necessarily went back to an earlier date..$^{32}$ (b) On the Greek side, it is well known

${ }^{26}$ Cf. J. H. Jongkees, "Kroiseios en Dareikos", Jaarbericht No. 9 van het Vooraziatisch-Egyptisch Gezelschap: Ex Oriente Lux (1944) 163-8, drawing on evidence from the hoard of coins discovered in the American excavations at Sardis, one group of which were certainly minted under the Persians; see T. L. Shear, "Sixth Preliminary Report on the American Excavations at Sardes in Asia Minor"

American Journal of Archaeology, second series, 26 (1922) 389-409 (397-9), and S. P. Noe, A Bibliography of Greek Coin Hoards, second edition, Numismatic Notes and Monographs 78 (1937) no. 927. Again, E. S. G. Robinson, "The Beginnings of Achaemenid Coinage" The Numismatic Chronicle, 6th series, 18 (1958) 187-93, comes to similar conclusions on the basis of two hoards from Tchai (45 miles east of Smyrna), published by S. P. Noe, Two Hoards of Persian Sigloi Numismatic Notes and Monographs 136 (1956).

${ }^{27}$ E. Herzfeld, "Notes on the Achaemenid Coinage and some Sassanian MintNames" Transactions of the International Numismatic Congress 1936, edited by J. Allan, H. Mattingly and E. S. G. Robinson, 413-26 (413-16); E. F. Schmidt, The Treasury of Persepolis and Other Discoveries in the Homeland of the Achaemenians, Communications of the Oriental Institute of the University of Chicago, 21, Chicago (1939) 76; full publication by S. P. Noe et al. in E. F. Schmidt, Persepolis II, Contents of the Treasury, Oriental Institute Publications 69, Chicago (1957) 110-4, pl. 84.

${ }^{28}$ A. Meillet, Grammaire du vieux-perse (1915) 67 (not available to me).

${ }^{29} \mathrm{E}$. Schwyzer, in an article in Indogermanische Forschungen 49 (1931) 1-45, discusses the main philologicai problems of Old Persian, Greek and Hebrew references to Darics on pp. 8-21. I am grateful to Dr. I. Gershevitch for initially drawing my attention to this article, which has generally been overlooked by the commentators, though it is now included in the new German lexicon: W.

Baumgartner et al., Hebräisches und aramäisches Lexikon zum alten Testament (Lieferung 1) E. J. Brill, Leiden (1967) 16.

${ }^{30}$ Cf. Schwyzer, 13, and R. G. Kent, Old Persian: Grammar, Texts, Lexicon American Oriental Society, New Haven (1950) 189.

${ }^{31}$ G. F. Hill, Catalogue of the Greek Coins of Arabia, Mesopotamia and Persia

The University Press, Oxford (1922) cxxf., observes that dareikos was also sometimes used by the Greeks for silver Persian coins.

32 Jongkees 166. 
that classical authors understood dareikos to be derived from the name Darius, ${ }^{33}$ attesting their belief that he was the first to mint these coins. Since this fits in exactly with the numismatic evidence referred to above, and is acceptable on linguistic grounds, ${ }^{34}$ there is no need to doubt the value of this evidence. What remains uncertain, however, is whether this is a loanword from the Old Persian for Daric, its explanation being merely a Greek Volksetymologie, or whether the name was in fact Greek from the start. (c) In the Old Testament, there are two similar words that appear to refer to coins in texts of the Persian period: 'a darkōnim in our 1 Chronicles 29:7 and Ezra 8:27, and dark ${ }^{\text {mōnim }}$ in Ezra 2:69=Nehemiah 7:70 and Nehemiah 7:69,71. Although the LXX is not of great help at this point, unfortunately, yet as far as it goes ${ }^{35}$ it would tend to support what is certainly on the surface the most attractive suggestion ${ }^{36}$ of seeing Drachmas in dark $^{e}$ mōnîm

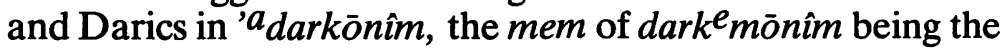
distinguishing factor. In both cases, the -ōn ending would reflect the Greek genitive plural. ${ }^{37}$ Both types of coin were, of course, current in the Persian period. ${ }^{38}$

I thus conclude that the author of 1 Chronicles $29: 7$ was most probably representing part of the offering for the preparation for temple building at the end of David's reign in terms of the Darics that were current in his own day, ${ }^{39}$ an

${ }^{33}$ Herodotus IV, 166; Pollux III, 87.

${ }^{34}$ Schwyzer 8-12.

${ }^{35}$ Darics are nowhere mentioned in the Greek Bible. Drachmas are mentioned in several passages, of which two are relevant to the present discussion. In the A text of Ezr. 2:69 it is used to translate $\operatorname{dark}^{e}$ mönim, and this supports the position defended above. At Ezr. 8:27, the A text also translates 'a darkōnim by "Drachmas". This may suggest that the two words in Hebrew were not distinguished, but it is equally possible to suppose that the Vorlage of LXXA also read dark ${ }^{e}$ mónim here; cf. Schwyzer, 16.

${ }^{36}$ See E. Meyer, Die Entstehung des Judenthums Max Niemeyer, Halle (1896) 196-7, who also adduces further supporting evidence from a bilingual Greek and Phoenician inscription from Piraeus in which both forms again occur. Meyer has been followed by, for instance, Schwyzer, 17-19, and W. Rudolph, Esra und Nehemia samt 3. Esra (HAT 20) J. C. B. Mohr, Tübingen (1949) 24.

${ }^{37}$ For the use of prosthetic 'aleph in a number of Iranian loan words, see E. Meyer, Die Entstehung des Judenthums 38.

${ }^{38}$ There is thus no need to follow W. F. Albright who revised his earlier opinion to suggest that all these passages refer to Drachmas; contrast $J B L 40$ (1921) 113 with Bi. Or. 17 (1960) 242.

${ }^{39}$ The suggestion that the word reflects the Assyrian darag mana (so conveniently H. Hamburger, $I D B$ I, 769) is rejected by Schwyzer, 14, and rightly, for the Assyrian phrase is not found in the modern dictionaries. 
innocent enough anachronism which is by no means unparalleled in modern translations and paraphrases of the Bible today. However, since no one has suggested relegating this passage to a secondary level of composition it appears that he could not then have written as early as Freedman, Cross and Newsome have suggested. ${ }^{40} \mathrm{With}$ that conclusion, however, their understanding of the Chronicler's purpose as somehow intending to support the hopes vested in Zerubbabel in the early years of Darius' reign and as attested in Haggai and Zc. 1-8 must be rejected.

It is perhaps worth taking this discussion yet one step further, for even if it were possible to date Chronicles as early as these scholars suggest, we would not necessarily then have to conclude that such a date was the most plausible on the evidence they themselves have advanced; indeed, there are certain difficulties in the way of this conclusion that have not so far been faced. These difficulties centre chiefly on the fact that despite the many similarities between Haggai and Zechariah, there are also differences of emphasis between them that should not be underestimated. It would take us far beyond our subject to discuss these points in detail, for there are several difficult matters concerning text (especially in Zc. 6:11-14), redaction and interpretation which would all require close examination first. Suffice it to say for the present, however, that virtually all major recent comparative studies of Haggai and Zechariah 1-8 agree that there are such differences of emphasis, and that they concern particularly

\footnotetext{
${ }^{40}$ They are, of course, at liberty to suggest alternative explanations, for instance that Darics were, despite the evidence we have referred to, minted before the time of Darius I, or that a later editor altered the original text of $1 \mathrm{Ch} .29: 7$ to suit it to the currency of his own day. The disadvantage of any such suggestion is its appearance of special pleading, seeking to avoid the implications of what is potentially one of the very few pieces of solid evidence for dating in the interests of a wider theory which must inevitably remain hypothetical. It would appear to be sounder method to move from what is more certain to what is less, rather than vice versa.
} 
the understanding of the role of Zerubbabel. ${ }^{41}$ Most noteworthy in this regard is that in Zechariah Joshua the high priest is far more prominent than in Haggai to the point where it is necessary to speak of the vision of a dyarchic form of leadership for the community. We may also observe a slight modification in Zechariah of Haggai's more overtly religiopolitical involvement. ${ }^{42}$

Although we must here enter the realm of speculation, it would seem most likely that this change was caused principally by two factors. On the one hand, although Ackroyd has demonstrated the difficulties of establishing any precise correlation between the dates supplied in these books and the turbulent course of events that marked the start of Darius' reign, ${ }^{43}$ yet even he finds significance in the date in Zechariah 1:7. He writes of the immediately following passage $(1: 8-17)$,

here the message given to the prophet is "behold, all the earth remains at rest." This message - indicating that rebellions in the empire are at an end - is so appropriate to the date given immediately before $(1: 7$, February 520$) \ldots$ that it would appear to be a strong argument in favor of the general correctness of that date, at least for this particular utterance (p. 18).

On the other hand, despite the persistent efforts of a

\footnotetext{
${ }^{41}$ E.g. P. R. Ackroyd, Exile and Restoration. A Study of Hebrew Thought of the Sixth Century BC (OTL) SCM Press, London (1968) 153-217; W. A. M. Beuken, Haggai-Sacharja 1-8: Studien zur Überlieferungsgeschichte der frühnachexilischen Prophetie (Studia Semitica Neerlandica 10) Van Gorgum, Assen (1967); K.-M. Beyse, Serubbabel und die Königserwartungen der Propheten Haggai und Sacharja. Eine historische und traditionsgeschichtliche Untersuchung (Arbeiten zur Theologie I/48) Calwer Verlag, Stuttgart (1972); K. Galling, "Serubbabel und der Wiederaufbau des Tempels in Jerusalem", in A. Kuschke (ed.), Verbannung und Heimkehr. Beiträge zur Geschichte und Theologie Israels im 6. und 5. Jahrhundert v. Chr. (W. Rudolph Festschrift) J. C. B. Mohr, Tübingen (1961) 67-96; idem., Studien zur Geschichte Israels im persischen Zeitalter J. C. B. Mohr, Tübingen (1964) 109-26 and 127-48; W. Rudolph, Haggai-Sacharja 1-8-Sacharja 9-14-Maleachi (KAT XIII 4) Gütersloher Verlagshaus Mohn, Gütersloh (1976) especially 153-6; G. Sauer, "Serubbabel in der Sicht Haggais und Sacharjas" in F. Maass (ed.), Das ferne und nahe Wort (Festschrift L. Rost; BZAW 105) Alfred Töpelmann, Berlin (1967) 199-207; K. Seybold, "Die Königserwartungen bei den Propheten Haggai und Sacharja" Judaica 28 (1972) 69-78.

${ }^{42}$ Beyse 37, who is more restrained in this regard than Sauer.

${ }^{43}$ P. R. Ackroyd, "Two Old Testament Historical Problems of the Early Persian Period” JNES 17 (1958) 13-27.
} 
number of scholars ${ }^{44}$ to implicate Zerubbabel in some conspiracy or rebellion, for which he was subsequently executed or removed from office, there is reasonable evidence to suggest that in fact the very opposite was the case. First, Darius explicitly confirmed Zerubbabel in his role as governor and temple builder after Tattenai and his colleagues had inquired (Ezr. 5:3-17) whether the rebuilding of the temple, which had already started, was permissible:

Now therefore, Tattenai, governor of the province Beyond the River, Shethar-bozenai, and your associates the governors who are in the province Beyond the River, keep away; let the work on this house of God alone; let the governor of the Jews and the elders of the Jews rebuild this house of God on its site (Ezr. 6:6-7).

This permission would not have been given if there was any suspicion of involvement in seditious activity. ${ }^{45}$ Second, it appears from the problematic Ezra 4 that "the adversaries of Judah and Benjamin" waited until the walls of Jerusalem were being rebuilt in the reign of Artaxerxes before accusing the city and its inhabitants of being "rebellious and wicked". Again, this delay would be hard to explain if there had been occasion for such an accusation in the earlier period. ${ }^{46} \mathrm{We}$ may thus conclude that Zerubbabel himself preferred not to make any capital whatever out of his Davidic ancestry.

Now Newsome speaks (p. 214) of the author of Chronicles and the prophets Haggai and Zechariah cherishing a political hope focussed upon the house of David in the person of Zerubbabel. If he wishes to be as particular as that, however, then we must observe that the evidence just adduced would strongly suggest that both external and internal developments caused these political hopes to be modified within months at most of their formulation. Since part of that modification is to introduce the high priest in a role and status which, as Beuken

${ }^{44}$ The most extreme statement of this position is L. Waterman, "The Camouflaged Purge of Three Messianic Conspirators" JNES 13 (1954) 73-8, but it has also been held by others in more moderate forms; e.g. A. T. Olmstead, History of the Persian Empire, The University Press, Chicago (sixth impression, 1970) 142.

Earlier suggestions along this line were criticized in particular by A. Bentzen, "Quelques remarques sur le mouvement messianique parmi les Juifs aux environs de l'an 520 avant Jésus-Christ" RHPhR 10 (1930) 493-503.

${ }^{45}$ Cf. K.-M. Beyse 45.

${ }^{46}$ Cf. K. Galling, "Serubbabel" 94-6, and Studien 147-8. 
has shown, ${ }^{47}$ could not have claimed support from Chronicles, we are left, on Newsome's understanding, with far too short a time to allow for the composition of so long and well

structured a work as 1 and 2 Chronicles, quite apart from the time that would have been needed to collect the material for that composition. If, on the other hand, Newsome does not wish to tie his interpretation so closely to political developments, then at once we must ask why Chronicles should be tied to the late sixth century $\mathrm{BC}$ at all. $\mathrm{He}$ argues that by $400 \mathrm{BC}$ "the prophetic decline was far advanced, and the Davidic kingdom was merely a memory" (p. 216). But how do we know? Newsome gives no evidence to support this assertion, whereas against it many would claim that there were still prophets active in Jerusalem considerably later than Haggai and Zechariah: Malachi certainly, Joel and Obadiah probably, ${ }^{48}$ and perhaps parts of other prophetic books according to one's views of their composition. As to the Davidic kingdom, the genealogy in 1 Chronicles 3 certainly comes down to a later date, as we have seen, and, whatever its relationship to the remainder of the book, it stands in its own right as a witness to a continuing interest in the Davidic line. Moreover, the fact that Nehemiah's opponents even considered it worth bringing a charge against him which said "you have also set up prophets to proclaim concerning you in Jerusalem, 'there is a king in Judah" "( Ne. 6:7) would suggest that they considered it possible that they would be believed. ${ }^{49}$ The attribution of Chronicles to the period of Haggai and Zẹchariah may thus be said to have difficulties which its proponents have not yet faced, and moreover to rest in the last resort on an argument from a silence which is in imminent danger of being broken.

Finally, Freedman, Cross and Newsome imply that the prophets and the Chronicler come from the same circle. It need hardly be said, however, that a general similarity on

${ }^{47}$ W. A. M. Beuken, Haggai-Sacharja 1-8 309-16.

${ }^{48}$ Cf. R. K. Harrison, Introduction 879 and 902.

${ }^{49}$ This would be even more significant if the suggestion that Nehemiah himself was of Davidic descent could be substantiated; but it remains very speculative: $U$. Kellermann, Nehemia. Quellen, Überlieferung und Geschichte (BZAW 102) Alfred Töpelmann, Berlin (1967) 154-9, and W.Th. In der Smitten, "Erwägungen zu Nehemias Davidizität" JSJ 5 (1974) 41-8, but cf. the critical comments of J. A. Emerton, JTS n.s. 23 (1972) 177-81. 
certain prominent issues is not sufficient to maintain this more specific hypothesis. The issue has been one of quite separate debate in recent years following the publication of Beuken's work already referred to. He argues with commendable thoroughness that Haggai and Zechariah 1-8 received their final editing in what is called a "Chronistically orientated milieu". We should observe at once that, of course, this in itself implies a certain distinction between the original oracles of the prophets and their editors who intended to interpret and reapply their message to a later generation, a distinction which forms the main basis for Beuken's detailed exposition. Beuken's view (which in any case presupposes the common authorship of Chronicles, Ezra and Nehemiah) has recently come in for a measure of what, in my opinion, is justified criticism, ${ }^{50}$ to which further points could be added without great difficulty. ${ }^{51}$ It follows, therefore, that here again we should be careful of associating these various works too closely.

On the basis of these various considerations, it may thus be concluded that the recent attempts to find an eschatology of a rather particular kind in Chronicles by way of an early dating must be rejected. We learn from this discussion, however, that our examination will need to be rather more closely involved with the texts themselves. The dangers of seeking to relate a historical book to a particular event in a later period are clear, and without much more evidence such attempts are likely to fail.

\footnotetext{
${ }^{50}$ W. Rudolph, Haggai-Sacharja 1-8 . . 23, 38f., etc., and especially R. A. Mason, "The Purpose of the 'Editorial Framework' of the Book of Haggai" VT 27 (1977) 413-21.

s' For instance, we might expect that in a "neutral" matter such as the use of titles there would be a similarity between the various works of a single school. However, in this case, we find just the opposite. A frequent and characteristic title for God in Haggai and Zc. 1-8 is "the Lord of Hosts", and some of its occurrences are generally attributed to the editor(s) of the books. Chronicles, however, shows a dislike for it: it is never found in material peculiar to Chronicles, and in three out of six cases where it is found in his Vorlage, it has been suppressed; cf. S. Japhet, Ideology, 25-6.

Similarly, for the title "high priest", Haggai and Zc. 1-8 regularly use the expression $h k h n h g d w l$, and again, this is frequent in passages that are most naturally understood as editorial, such as the narrative introductions to the oracles. In Chronicles, however, this title is only found once, at $2 \mathrm{Ch} .34: 9$, where it is drawn unchanged from $2 \mathrm{Ki}$. 22:4. Elsewhere, both in passages peculiar to Chronicles, and in passages where the Chronicler has altered or suppressed his Vorlage, he uses instead khn hr's; see S. Japhet, VT 18 (1968) 343-4.
} 
An alternative approach to our problem may be said to link some aspects of the works of a number of scholars which otherwise differ quite markedly. ${ }^{52}$ On this view, the Chronicler is thought so to have heightened his portrayal of the glories of a past age as to stimulate within his readers the hopes for a return to these conditions in an eschatological, or quasi-eschatological, dimension. This is usually discussed with particular reference to the person and reign of David, though in a more recent study Mosis has attempted to refine this approach much further. ${ }^{53}$ In his view, the reigns of Saul, David and Solomon are paradigms of three possible situations in which later Israel may find herself; Saul is representative of apostasy and failure, in brief, of exile, whereas David is more the pattern for restoration, a transition from loss to salvation, and yet (and this is Mosis' distinctive contribution) his reign is not in itself a period of final attainment. It is, rather, preparatory to ultimate fulfilment, typified by the Chronicler's presentation of the reign of Solomon. ${ }^{54}$ Subsequent kings, and indeed the post-exilic restoration, are found to have parallels with either the reign of Saul or of David; the Solomonic epoch remains as a pattern for future, even eschatological, hope and aspiration. ${ }^{55}$

${ }^{52}$ E.g. G. von Rad, Geschichtsbild 119-32, and Theologie des alten Testaments I (zweite Auflage) Chr. Kaiser, Munich (1958) 347-8 (E.T., Old Testament Theology I Oliver and Boyd, Edinburgh and London (1962) 350-1); A. Noordtzij, "Les intentions du Chroniste" RB 49 (1940) 161-8; A.-M. Brunet, "Le Chroniste et ses sources" $R B 60$ (1953) 481-508 and 61 (1954) 349-86, and "La théologie du Chroniste: théocratie et messianisme" Sacra Pagina I (ed. J. Coppens et al.; Ephemeridum Theologicarum Lovaniensium XII-XIII, 1959) 384-97; G. J. Botterweck, "Zur Eigenart der chronistischen Davidgeschichte" Th. $Q 136$ (1956) 402-35; W. F. Stinespring, "Eschatology in Chronicles" JBL 80 (1961) 209-19; R. North, "Theology of the Chronicler" JBL 82 (1963) 369-81; F. Michaeli, Les Livres des Chroniques, d'Esdras et de Néhémie (CAT 16) Delachaux et Niestlé, Neuchâtel (1967) 31-2.

${ }^{53}$ R. Mosis, Untersuchungen zur Theologie des chronistischen Geschichtswerkes (Freiburger theologische Studien 92) Herder, Freiburg (1973). Mosis' approach to the Chronicler has received a measure of approval, at any rate by comparison with that of T. Willi, Die Chronik als Auslegung (FRLANT 106) Vandenhoeck \& Ruprecht, Göttingen (1972), from P. R. Ackroyd, "The Chronicler as Exegete" JSOT 2 (1977) 2-32.

${ }^{54}$ See in particular pp. 164-9.

ss "Der Chr gestaltet also seine Salomogeschichte nach der in 2 Makk 2, lff bezeugten, endzeitlichen Heilserwartung und entwirft damit ein Bild des Heils, das zu seiner Zeit, der Zeit des zweiten Tempels, noch aussteht und dessen Kommen er für eine noch zukünftige Zeit erwartet" (p. 163). 
Concerning the first group of studies just mentioned, it must be said that although it may superficially seem difficult to find any major objection, yet often they are expressed in such general terms that the conclusions drawn are inevitably somewhat subjective. This is shown particularly by the fact that the same evidence has clearly failed to impress Rudolph, Plöger and others. In fact, however, although it is certainly true that the portrayal of David is more favourable in Chronicles than in Samuel and Kings, yet, as Japhet has shown, ${ }^{56}$ enough unfavourable elements remain to suggest that it cannot be termed "idealized". How, then, can we be sure that the Chronicler's purpose was that which these scholars claim? Their approach could only win approval if first they could point to some specific texts which indicated that this was in fact in the mind of the Chronicler.

Mosis, on the other hand, might claim that his detailed study avoids these dangers. In consequence, however, it lays itself open to more rigid scrutiny which suggests that he may have erred in three important respects. ${ }^{57}$ First, whereas it is true that Solomon's character is portrayed in Chronicles as blameless, yet that again does not make of him the idealized figure that Mosis suggests. His dependence upon his father's preparations for the successful building of the temple is only the most striking example of this fact. ${ }^{58}$ Secondly, as will become apparent later, I agree with Japhet and Braun ${ }^{59}$ that the Chronicler has endeavoured to present the reigns of David and Solomon as a unity. Though neither on his own is an idealized figure, yet the period of their rule as a whole is presented in a most positive fashion. It is thus questionable whether the division which Mosis drives between them, so crucial for his interpretation, can be maintained in the form

${ }^{56} \mathrm{~S}$. Japhet, Ideology 468-72, drawing attention in particular to $1 \mathrm{Ch} .21,1 \mathrm{Ch} .13$ with 15:11-15 and $1 \mathrm{Ch}$. 22:7-8, 28:3.

${ }^{57}$ P. R. Ackroyd, JSOT 2 (1977) 2-32, makes a number of criticisms of details in Mosis' arguments, though he does not necessarily think that these invalidate Mosis' position as a.whole. They are thus in a rather different category from those listed above, and so need not be pursued further here.

s8 I have developed this theme more fully in "The Accession of Solomon in the Books of Chronicles" VT 26 (1976) 351-61; see further S. Japhet, Ideology 476-81.

${ }^{59}$ See the references in the previous note, together with R. L. Braun, "Solomonic Apologetic in Chronicles" JBL 92 (1973) 503-16; "Solomon, the Chosen Temple Builder: the Significance of 1 Chronicles 22, 28, and 29 for the Theology of Chronicles" JBL 95 (1976) 581-90, and "The Message of Chronicles: Rally 'Round the Temple" CTM 22 (1971) 502-14. 
that he sets out. Thirdly, it has been suggested that the Chronicler modelled his presentation of the reign of Hezekiah on that of Solomon, not David, and that Mosis' attempts to find "Davidic" elements in Hezekiah are unsuccessful. ${ }^{60}$ If this suggestion is correct, Solomon's reign can no longer serve as a unique pattern of eschatological bliss.

We conclude from these observations, therefore, that although this second main approach to our topic has much to commend it over the first, it by no means exhausts the subject. In particular, there is a clear need to deal with the texts themselves, rather than resting content with vague generalizations about the Chronicler's portrayals of character.

\section{The Dynastic Oracle}

The most promising approach is likely to be by way of a study of the position of the king in Chronicles since, as is well known, the whole work is very much built around the Davidic dynasty. Clearly, our particular concern must be to examine whether the Chronicler thought that the promises to David, which of course were of eternal significance, were of such a kind as to lead him to expect the emergence of a king some time in the future in Jerusalem, or whether, as so many have argued, he presented his history in such a way as to suggest that the significance of these promises had been transferred to the temple and its cultus, so that no particular further change in the theocracy was to be expected. Inevitably, we must start with an examination of the Chronicler's presentation and interpretation of the dynastic oracle. ${ }^{61}$

Two main types of evidence have been advanced in the past in the attempt to resolve this point, and it is noteworthy that both have been claimed in support of each position. A brief review of the salient points of this discussion will provide the context in which a new suggestion for the resolution of this difficulty may be understood.

${ }^{60}$ Israel in the Books of Chronicles 119-25.

${ }^{61}$ In this section, I draw, with permission, on my contribution, entitled "The Dynastic Oracle in the Books of Chronicles", to the forthcoming Festschrift for Prof. I. L. Seeligmann of Jerusalem. Some of the positions maintained here are based on more detailed evidence presented there. 
Comparison of 1 Chronicles 17 with 2 Samuel 7 (the Nathan oracle) shows that there is a clear literary relationship between the two. The differences between them, however, have been variously explained. Crucial to the discussion is the significance of the difference between 2 Samuel 7:12b - "I will raise up your offspring after you, who shall come forth from your body, and I will establish his kingdom" - and its parallel in 1 Chronicles 17:11, which the RSV translates: "I will raise up your offspring after you, one of your own sons, and I will establish his kingdom". Proponents of the theocratic view argue that the translation of RSV is correct, and that in consequence the promise is restricted by the Chronicler to Solomon alone. ${ }^{62}$ Those who favour the messianic, or royalist, position, by contrast, follow Keil in translating "who shall come forth from your sons". ${ }^{63}$

Examination of the use elsewhere in the Old Testament of the disputed phrase hyh mn (lit. "to be from") shows, however, that on its own it is ambiguous; passages can be found to support both the proposed translations. ${ }^{64}$ Moreover, since it is also sometimes used in clear parallel with $y s^{\prime} \mathrm{mn},{ }^{65}$ the phrase found in 2 Samuel 7:12, it would appear that for whatever reason the difference arose, ${ }^{66}$ it is of little substantial significance as far as meaning is concerned.

If this be allowed, we can then move on to observe that the emphasis of the remainder of the oracle is slightly directed

${ }^{62}$ E.g. E. L. Curtis and A. A. Madsen, A Critical and Exegetical Commentary on the Books of Chronicles (ICC) T. and T. Clark, Edinburgh (1910) 229; W. Rudolph, Chronikbücher 133; A. Caquot, "Peut-on parler de messianisme dans l'oeuvre du Chroniste?" RTP 3/16 (1966) 110-20 (116).

${ }^{63}$ C. F. Keil, Biblischer Commentar 163-4; G. von Rad, Geschichtsbild 123-4, and Theologie I348, n.9; A. Noordtzij, "Les Intentions" 163; K. Galling, Die Bücher der Chronik 54; G. J. Botterweck, "Eigenart" 422.

${ }^{64}$ For details, see "The Dynastic Oracle".

${ }^{65}$ E.g. Gen. 17:6 and 16, discussed by I. L. Seeligmann, Tarbiz 25 (1955-6) 129; Jer. 30:21. In addition, S. Japhet, Ideology 489, observes that bnyk and ys'y m' $y k$ are synonymous expressions, as comparison of the parallel texts $2 \mathrm{Ki}$. 19:37 (Qere), Is. $37: 38$ and 2 Ch. 32:21 shows.

${ }^{66}$ The most probable suggestion is that this is a slight change for stylistic purposes, though recent studies have tended to underline the difficulties of pinpointing the origin of such changes; see S. Talmon, "Synonymous readings in the textual traditions of the Old Testament", Scripta Hierosolymitana 8 (1961) 335-83; W. E. Lemke, "The Synoptic Problem in the Chronicler's History" HTR 58 (1965) 349-63. We thus can never be sure that the Chronicler was not just reproducing his Vorlage faithfully, or even that the Samuel text is not secondary at this point: this is almost certainly so in some cases in these chapters, though we cannot go so far in this direction as H. van den Bussche, ETL 24 (1948) 354-94. 
towards Solomon. ${ }^{67}$ This is made most clear in 1 Chronicles 17:14: "But I will confirm him in my house and in my kingdom for ever and his throne shall be established for ever", where the third person singular pronouns, which in the context (see verse 12) can refer only to Solomon, should be compared with the second person singular pronouns (referring to David) of the Vorlage in 2 Samuel 7:16:68 "And your house and your kingdom shall be made sure for ever before me; your throne shall be established for ever".

It follows from this conclusion, first, that the significance of the omission from 1 Chronicles 17 of the sentence in 2 Samuel 7:14 about the possible need to discipline David's successor should be interpreted exclusively in terms of the Chronicler's understanding of the role of Solomon, to which we must return below; and secondly, that at this stage in the Chronicler's narrative we may even have to concede that the expression "the Lord will build you a house" $(1 \mathrm{Ch} .17: 10)$ has been applied by the context to Solomon alone, with the promise of an established dynasty thrown forward on to Solomon for purposes and with consequences which remain to be determined.

Up to this point, therefore, we agree with those whose understanding of 1 Chronicles 17 leads them to oppose a messianic, and on the whole even a royalist, interpretation.

${ }^{67}$ It should be noted that David's prayer in response to the oracle (1 Ch. 17:16-27) is apparently adopted by the Chronicler without any significant or tendentious alteration. Its stress on the eternal validity of the promise may be thought to create a certain tension with the focussing of the oracle itself on Solomon, as maintained above, and this must be discussed later. The heart of the prayer (1 Ch. 17:25), however, could well be interpreted as applying primarily to Solomon, and was probably so understood by the Chronicler.

${ }^{68}$ It has recently been pointed out by T. N. D. Mettinger, King and Messiah (ConB. Old Testament Series 8), Gleerup, Lund (1976) 57-8, that the LXX of 2 Sa. 7:16 here agrees with 1 Ch. 17:14 (MT and LXX) against its MT Vorlage. His suggestion that "the LXX reading has preserved a tradition that goes back to the original Solomonic document of Solomon's legitimation", of which the MT is a later, dynastic redaction, must be judged implausible. Unless we are to take the view that the text in Samuel is the outcome of very much later editorial manipulation, two possibilities remain open: either the Chronicler had a Vorlage which already differed from the MT of Samuel, and whose reading is attested in the LXX, as suggested for comparable situations at a number of other texts by Lemke, or the LXX of $2 \mathrm{Sa}$. 7:16 reflects an assimilation to the Chronicler's text at either the Hebrew or Greek stage of its development. Whilst certainty is completely unattainable here, it remains true that the MT of Samuel and Chronicles at this point seems so to coincide with the overall thrust of its context in the respective passages that the second alternative is the more probable (cf. M. Simon, RHPhR 32 [1952] 46-7). 
This conclusion, however, by no means exhausts the subject, for the Chronicler often conveys his message by way of his larger narrative structure. His handling of the dynastic oracle in 1 Chronicles 17 is but one element of this larger whole, and rash conclusions concerning his Tendenz should thus not be drawn hastily from a single text without further ado.

The second approach to an understanding of the Chronicler's interpretation of the dynastic oracle is through the references to it in his subsequent narrative. Here again, the significance of this material has been assessed in widely differing ways.

On the one hand, Newsome has most recently argued, ${ }^{69}$ on the basis of 1 Chronicles 22:9-10 and 28:6-7, that "Chronicles' interest in the Davidic kingdom is actually an interest in eschatology" (p. 213), for these texts are said not only to amplify the oracle of Nathan, but particularly to heighten the stress on the perpetuity of the Davidic dynasty (pp. 208-10). (Whilst we have already noted some difficulties for Newsome's conclusions about the dating of Chronicles, his interpretation of the texts is a separate issue which still requires examination.)

On the other hand, as far as our present interest is concerned, it is a serious weakness in Newsome's case that he completely fails to deal with two important emphases of these texts to which other scholars have drawn attention, and from which they have arrived at quite contrary conclusions. First, it is impossible to deny that in the speeches of David in 1 Chronicles 22,28 and 29 the dynastic oracle is linked very closely indeed with the election of Solomon as David's successor. Thus, in 1 Chronicles 22:6-10, David relates to Solomon what must be intended as a verbatim account of the oracle as he received it, and indeed there are some clear and substantial points of literary contact (compare 1. Ch. 17:12-13a with 22:10). Included in the oracle, however, is a reference to Solomon by name, 1 Chronicles 22:9:

Behold, a son shall be born to you; he shall be a man of peace. I will give him peace from all his enemies round

\footnotetext{
${ }^{69} \mathrm{~J}$. D. Newsome, “Toward a New Understanding". Newsome's presentation is the most extreme of a line of interpretation found also (inter alia) in J. W. Rothstein and J. Hänel, Kommentar zum ersten Buch der Chronik (KAT 18) Deichert, Leipzig (1927) xliv; G. J. Botterweck, "Eigenart" 422, 430-31; A.-M. Brunet, "La théologie du Chroniste".
} 
about; for his name shall be Solomon, and I will give peace and quiet to Israel in his days.

It is curious that Newsome, who cites part of this and the following verse, chooses to omit from his citation those very phrases in which the application of the promise to Solomon is made explicit.

Similarly, in 1 Chronicles 28, where David addresses the people, he again refers to the dynastic oracle in such a way as to link it inseparably with Solomon:

He said to me, 'It is Solomon your son who shall build my house and my courts, for I have chosen him to be my son, and I will be his father. I will establish his kingdom for ever if he continues resolute in keeping my commandments and my ordinances, as he is today' (verses 6-7).

Whilst Newsome cites this passage in full, he again completely fails to take account of the emphasis on Solomon as the recipient of the promise.

A related theme to which this passage also refers is that of the divine election of Solomon as king. Several scholars have noted that Chronicles is unique in making Solomon the object of God's chöice (bhr), ${ }^{70}$ and although at 1 Chronicles 28:10 and 29:1 it is related only to the building of the temple,${ }^{71}$ yet at its other two occurrences ( $1 \mathrm{Ch} .28: 5$ and 6$)$ it is brought into the closest possible association with the dynastic oracle. In consequence, the first point to be made from the Chronicler's own interpretation of this oracle in his subsequent narrative is that there is a heavy emphasis upon its particular application to Solomon. That this does not fully exhaust its significance is clear from several passages that relate to kings later than Solomon, as will shortly be seen more fully, but there is nevertheless a stress here in the Chronicler's narrative which is lacking in his Vorlage, and to which Newsome has failed to do justice. It need hardly be added that this conclusion confirms the approach to the Chronicler's Tendenz in 1

\footnotetext{
${ }^{70}$ E.g. G. E. Mendenhall, IDB II, 78; I. L. Seeligmann, “mmșy'wt hysțwryt ltpysh hysțwrywswpyt bmqr"' prqym 2 (1969-74) 273-313 (300); S. Japhet, Ideology 448-51; R. L. Braun, "Solomon, the Chosen Temple Builder".

"It should nevertheless be noted that this is itself a major theme of $1 \mathrm{Ch} .17$, and that the designation during David's lifetime of Solomon as the temple builder is already a step towards the application of the oracle to Solomon, whereas in Kings this connection is not made until after the temple has been built (1 Ki. 8:19-20), as observed by S. Japhet, Ideology 449.
} 
Chronicles 17 itself which we favoured above.

The second feature of these speeches of David that deserves fuller attention is the conditional element which they import into the promise of a dynasty, ${ }^{72}$ apparent particularly at 1 Chronicles 28:7 and 9; 2 Chronicles 6:16; 7:17-18.

1 Chronicles 22:12-13, which is usually compared at this point, is in reality to be distinguished from these other passages, for though it is certainly conditional, it is not directly linked to the establishment of the dynasty, but rather with Solomon's prosperity. ${ }^{73}$ It is true that just previously (verse 10) the promise of an eternal dynasty has been referred to, but the immediate context (verses 11 and 14) shows that this "prosperity" is to be understood primarily in terms of temple building. This leaves 1 Chronicles 22:10 as an isolated example of an unconditional repetition of the promise of a dynasty.

A way quite different from Newsome's silence of avoiding the implications of this material is that advanced by Mosis (whose position is otherwise at the opposite extreme), who attempts to relegate 1 Chronicles $22: 12-13$ and $28: 7 b-10$ to the realm of secondary expansion, to be ignored, in consequence, in any estimate of the Chronicler's ideology. ${ }^{74}$ Mosis' main argument in favour of this suggestion is that these verses are impossible to reconcile with other passages where the Chronicler has deleted a concession in his Vorlage to the very possibility that Solomon might sin: 1 Chronicles 17:13 and 2 Chronicles $1: 12$ (contrast $1 \mathrm{Ki} .3: 14$ ). This, however, is quite unacceptable, for such a possibility is conceded by the

\footnotetext{
${ }^{72}$ Newsome is aware of this element, but merely refers in a footnote to the treatment of D. N. Freedman, "The Chronicler's Purpose". However, this is not sufficient for the present purpose, for Freedman does not explain the intention of these verses in both Chronicles and Kings where the whole future of the dynasty itself is made conditional on the king's obedience. In fairness, it should be said that in his unpublished doctoral dissertation (The Chronicler's View of Prophecy 136), Newsome does agree that " 1 Chronicles 28:7 depicts David (in a prophetic utterance) affirming that the eternity of the Davidic house is conditional upon the king's faithfulness to Yahweh", but even there he fails to integrate this observation into his overall conclusions.

${ }^{73}$ Contra S. Japhet, Ideology 461. A similar objection may be levelled against A. Caquot, "Peut-on parler de messianisme ...?" 116, who refers only to $1 \mathrm{Ch} .28: 20$ to support his claim that the Chronicler has no interest in Solomon's future apart from temple building. However, since he makes no reference whatsoever to such passages as $1 \mathrm{Ch} .22: 10,28: 7$ etc., his interpretation must be discounted as one-sided.

${ }^{74}$ R. Mosis, Untersuchungen 90-2.
} 
Chronicler at 2 Chronicles 6:16 and especially 7:17. It is not true to say that 6:16 refers only to the later Davidides, ${ }^{75}$ for the antecedent of the pronoun in "your sons" is David himself, so that Solomon must at least be included; in fact, however, it would even seem that the reference is primarily to him, for verse 15 speaks of the fact that the first part of the promise to David (that his son would build the temple) has been fulfilled "this day". In 7:17, the case is even stronger, the text making it quite clear that Solomon alone is referred to: "And as for you, if you walk before me, as David your father walked ..." ${ }^{76}$ Finally, not only do these passages not contradict the position of the Chronicler as expressed elsewhere, but we shall in fact seek to show that they contribute substantially to his overall presentation.

In contrast to these rather extreme positions, a more moderate line is advanced in this regard by Japhet. ${ }^{77}$ She reminds us first of the tension in the books of Samuel and Kings between the two presentations of the oracle of Nathan, for in 2 Samuel 7 the promise of an eternal dynasty to the Davidic family is absolute and unconditional, whereas in 1 Kings 8:25 (and cf. 2:4 and 9:5) there is a change of emphasis by which the establishment of the promise is made dependent on (Deuteronomistically expressed) obedience to God's law. In Chronicles, however, Japhet argues first that the omission of 2 Samuel $7: 14 b$ in fact softens the unconditional nature of the promise, for its purpose in 2 Samuel was to emphasize that even if an individual king sinned and was punished, this would not affect the continuity of the dynasty itself. She is then able to go on to show that the passages in 1 Chronicles 22 and 28 confirm this impression, for though for the most part they virtually cite the oracle of 1 Chronicles 17 verbatim, yet they harmonize it with the Deuteronomic presentation by

${ }^{75}$ Contra Mosis, Untersuchungen 90.

${ }^{76}$ Mosis' other arguments for deleting these verses are even less convincing. For instance, he notes that a number of scholars (e.g. W. Rudolph, Chronikbücher 151-2) regard the end of $1 \mathrm{Ch} .22$ as secondary, but this concerns verses $14-19$ only, so that there is really no good reason to extend the expansion back to include verses $12-13$, as Mosis suggests. Moreover, the verses in $1 \mathrm{Ch} .22$ and 28 are integral parts of larger forms which, it has been argued, play a significant role in the structure of the Chronicler's work as a whole; cf. my "The Accession of Solomon", and R. L. Braun, "Solomon, the Chosen Temple Builder".

${ }_{77}$ S. Japhet, Ideology 457-63; and cf. in part I. L. Seeligmann, “ $m m s y$ 'wt hystwryt" $301 \mathrm{ff}$. 
introducing a conditional clause at the very point where 2 Samuel 7:14b was omitted (cf. 1 Ch. 28:7).

Japhet has more difficulty, however, in fitting into her scheme the allusions to the dynastic oracle in 2 Chronicles $13: 5,21: 7$ and $23: 3$. She explains away the first by observing that though no condition is expressed, there is at least a heavy emphasis on the assertion of cultic obedience by Abijah and the Jerusalem community. The other two occurrences come from a period of grave threat to the dynasty, so that the Chronicler was justified in returning to the aspect of unconditional promise to David.

From this discussion of studies of 1 Chronicles 17 and its echoes in the later chapters of the Chronicler's work, apparently conflicting viewpoints have emerged. This concerns chiefly the fact that on the one hand we have noted a marked tendency to concentrate the attention of the oracle exclusively on Solomon, whilst on the other there is an emphasis on those conditional elements which in the Deuteronomic presentation were intended primarily to refer to the failings of the later kings as an explanation for the fall of the dynasty in the Babylonian exile. ${ }^{78}$ Furthermore, the Chronicler has retained the references of his Vorlage to "eternity" in connection with the dynastic promise, and carried them over into his own later applications of the oracle (cf. 1 Ch. 17:12, 14, 17, 23, 24, 27;22:10;28:7, 8), which again might be considered inappropriate if the promise relates to Solomon alone. ${ }^{79}$

It may, however, be suggested that all these factors can be explained on the basis of a feature of the Chronicler's narrative to which attention has already been drawn,${ }^{80}$ namely his concern to present the reigns of David and Solomon as a single, unified event within the divine economy for the life of the nation, in which the complementary nature of the two kings' functions plays an important role, a feature most

${ }^{78}$ See I. L. Seeligmann, “mmșy'wt hysṭwryt” 308-10.

${ }^{79}$ This point is conceded by Rudolph, Chronikbücher 137, and is emphasized by J. M. Myers, 1 Chronicles (AB 12), Doubleday, Garden City (1965) 129. The "elasticity" of the oracle itself is stressed particularly by N. Poulssen, König und Tempel im Glaubenszeugnis des Alten Testaments (SBM 3), Katholisches Bibelwerk, Stuttgart (1967) 171-4.

${ }^{80} \mathrm{See}$ the works referred to in notes 58 and 59 above. 
marked in the Chronicler's handling of the theme of temple building.

In the books of Samuel and Kings, Solomon makes no particular contribution to the establishment of the dynasty. The unconditional promise is addressed directly to David (2 Sa. 7) in such a way that, although it arises from a concern for, and remains closely associated with, the emergence of Solomon as the temple builder, the two themes can nevertheless be kept apart and treated in isolation. Equally, the interpretation of the promise on a conditional basis which comes later does not distinguish Solomon from his successors, and indeed, it is in particular the sin of Manasseh which is said to lead to the final catastrophe.

The Chronicler, in contrast, by way of his distinctive presentation of the united monarchy, would seem to have attempted to harmonize the tensions of his Vorlage: just as the dynastic oracle, as delivered originally to David, is concentrated upon the person of his son Solomon, so too the conditions of obedience, whose fulfilment will lead to the establishment of an eternal dynasty, are focussed upon him (1 Ch. 28:7). ${ }^{81}$ This at once, of course, has the effect of making Solomon's role a foundation for the future of the dynasty equal with David's for upon Solomon's obedience the whole of that future will depend. The establishment of an eternal dynasty thus rests on two indispensable elements: the promise of God to David, and the carrying out of God's conditions by Solomon. Neither element would suffice in itself, and equally neither David's nor Solomon's part in this scheme could have been fulfilled without the other, for the promise to David would clearly have been void without Solomon, whilst of Solomon it is said that he could not have managed to complete the temple (and thus fulfil the major demand upon him) without the help of David's preparation (1 Ch. 22:5; 29:1-2).

\footnotetext{
${ }^{81}$ This will explain the Chronicler's omission of "or your children" from $1 \mathrm{Ki}$. 9:6 at $2 \mathrm{Ch} .7: 19$, which has not been adequately treated by the commentators. In Kings, the condition of obedience is laid by God on Solomon and his descendants without distinction. This is changed in the present form of the Chronicler's text (contra J. Goettsberger, Die Bücher der Chronik oder Paralipomenon (Die heilige Schrift des alten Testaments 4/1) Peter Hanstein, Bonn (1939) 236) to a reference to Solomon and his people. The effect of this is to limit the conditional aspect of the promise of a dynasty in verses 17-18 to Solomon alone; see further below.
} 
In the passages where this theme is explicit, two aspects of obedience receive attention; the one is specific, the building of the temple, and the other quite general, the keeping of God's commandments and ordinances. What is more, it is well known that the Chronicler's account of Solomon's reign presents him as one who did in fact keep both these conditions, ${ }^{82}$ and that in as positive a way as it is possible to conceive. ${ }^{83}$ Finally, the Chronicler's omission of 2 Samuel $7: 14 b$ may be explained at this point, for it becomes clear that this was certainly not a matter of his hesitation in even granting the possibility that Solomon might be disobedient (contra Mosis); nor was it only - though we readily agree that it may have included - an attempt to eliminate from the oracle a sentence whose effect was to make the promise of the dynasty as a whole so definitely unconditional (contra Japhet). It was rather, we suggest, that the Chronicler's focussing of the oracle upon Solomon made the inclusion of this clause quite irrelevant. In the Samuel text, it refers to the whole future line of Davidic kings, to many of whom the saying could have applied, whereas for Solomon in the Chronicler's scheme it could have no application whatever. Either he was going to obey, in which case the dynasty would be established, or he would fail, and his house with him; the possibility was not foreseen that he would fail personally, but the dynasty nevertheless endure.

\section{Later development}

Our contention, then, is that, with the completion of the period of Davidic-Solomonic rule, the Chronicler intends his readers to understand that the dynasty has been eternally established. We have not found evidence to justify the view that with Solomon's building of the temple the content of the promise was exhausted, but rather that the completion of the temple was a contributory factor to the establishment of the

${ }^{82}$ Cf. R. Mosis, Untersuchungen 125-63, and especially R. L. Braun, "Solomonic Apologetic". 1 Ch. 28:7 states explicitly that at that time Solomon was keeping the necessary conditions; the subsequent narrative would give the reader of Chronicles no cause to suppose that this changed in any particular.

${ }^{83}$ See 1 Ch. 28:23; 2 Ch. 1:1, 9-10 with God's positive answer; $2: 11 ; 6: 8-10,15-16$; $9: 22$, in addition to the well-known passing over of the apostasy of Solomon in $1 \mathrm{Ki}$. 10. 
promise. We must now move on, therefore, to see whether there are any other indications to support this understanding. (1) 2 Chronicles 6:41-2.2 Chronicles 6 is mainly taken up with Solomon's prayer at the dedication of the temple. On the whole, it follows 1 Kings 8 very closely. A change of emphasis that does seem to be deliberate, however, is seen in the fact that the three references to the Exodus and Sinai at 1 Kings $8: 21,51$ and 53 have been either reduced or altered. ${ }^{84}$ The third instance is in fact the close of the prayer, the reference to the Exodus forming the basis for Solomon's appeal to God to answer him. The full explanation of this phenomenon cannot concern us here ${ }^{85}$ but it is relevant to observe that the Chronicler has substituted new material to form a quite different conclusion to the prayer (2 Ch. 6:41-2):

And now arise, O Lord God, and go to thy resting place, thou and the ark of thy might.

Let thy priests, O Lord God, be clothed with salvation and let thy saints rejoice in thy goodness.

O Lord God, do not turn away the face of thy anointed one! Remember thy steadfast love for David thy servant.

These lines comprise mainly a citation of Psalm 132:8-10. Although there are several minor differences between the texts, the only one of immediate significance comes in the last two lines, for Psalm 132:10 reads:

For thy servant David's sake

do not turn away the face of thy anointed one.

It is to be noted first that the order of the two lines has been inverted by the Chronicler, and secondly that he has altered it to "Remember thy steadfast love for David" by introducing what we can only understand as an allusion to Isaiah $55: 3 b$ ("And I will make with you an everlasting covenant, my steadfast sure love for David"). We would suggest that this was both to give added emphasis to this line and to remove a possible ambiguity inherent in the words "for David's sake".

The first of these two points is clear enough. Concerning the second, we need to remember that Psalm 132 deals with two related themes, the transfer of the Ark to Jerusalem and $382-8$.

${ }^{84}$ See A.-M. Brunet, "La théologie du Chroniste", and S. Japhet, Ideology

${ }^{85}$ See Israel in the Books of Chronicles 64-6 for an introductory account. 
God's promise to David. Verse 10 marks the transition between the two halves, so that it is not clear whether "for David's sake" means because of his faithfulness and loyalty ${ }^{86}$ or because of God's promise to him. The former could find support in the first verse of the Psalm:

Remember, O Lord, in David's favour, all the hardships he endured, whereas the latter can appeal to the verses that follow (11-12, 17). ${ }^{87}$

Whatever be the true interpretation of the Psalm, three considerations lead me to conclude that the Chronicler means us to understand his rephrased line as a reference to God's promise to David. First, this is the meaning of the phrase in Isaiah 55:3. It is true that there have recently been some attempts to suggest that it is a subjective genitive there too ("David's loyal acts"), ${ }^{88}$ but I have endeavoured to show in considerable detail elsewhere ${ }^{89}$ both that the arguments in favour of this position are not compelling, and that others point very forcibly indeed to the rendering "steadfast love for "David". 90 Secondly, the context in the prayer of Solomon

\footnotetext{
${ }^{86}$ So, for instance, A. A. Anderson, The Book of Psalms, Volume 2 (NCB) Oliphants, London (1972) 883.

${ }^{87}$ For an analysis of the Psalm along these lines, see T. E. Fretheim, "Psalm 132: a Form-Critical Study"JBL 86 (1967) 289-300. W. A. M. Beuken understands the implications of Fretheim's study in this regard differently; see "Isa. 55, 3-5: the Reinterpretation of David" Bijdragen 35 (1974) 49-64 (52, n.19). It is true that Fretheim points to some parallels between verses 1 and 10 , but he then goes on (p. 292 ) to stress that there are also "some notable differences between the two strophes" $1-5$ and 10-12, the main one being precisely the difference between a supplication to remember the Davidic hardships in fulfilling his vow to God in the past (v.1) and (v.10) God's fulfilling his vow to David in the present.

${ }^{88}$ Principally A. Caquot, "Les 'grâces de David'. A propos d'Isaie 55/3b" Semitica 15 (1965) 45-59, and W. A. M. Beuken, "Isa. 55, 3-5".

k9 “.'The Sure Mercies of David': Subjective or Objective Genitive?", JSS 23 (1978) 31-49.

${ }^{90}$ Proponents of the alternative view point in particular to the use of this same word (hśdym) with the meaning of "pious deeds" at 2 Ch. 32:32 and 35:26 and compare also the use at Ne. 13:14; in addition to the works cited above, see in particular M. Adinolfi, "Le 'opere di pietà liturgica' di David in 2 Cron. 6, 42" Bibbia e Oriente 7 (1966) 31-6. It should be said in reply, however, that whereas these passages show that the word may be used of "pious deeds", in my view the even closer parallel of Is. 55:3 and the context in $2 \mathrm{Ch} .6$ should, from the point of view of method, be given greater weight, and both strongly favour the translation adopted
} 
points the same way, for it will then balance the opening of the prayer in 2 Chronicles 6:15-17, with its strong emphasis upon God's keeping his promise to David up until the time of temple building and its request that God will now go on to confirm that word of promise. ${ }^{91}$ Thirdly, as we have seen, in the Chronicler's understanding of the united monarchy, the emphasis falls on the promise to David and obedience to the conditions by Solomon. Thus an appeal to David's pious deeds at this point would be less appropriate to his overall presentation.

We are now in a position to see the significance of these verses for the Chronicler's theology. On the one hand, his allusion to Isaiah 55:3 must be seen as an attempt to re-emphasize the royalist interpretation of the promise to David over against Isaiah 55:3 which, as is now generally recognized, appears to transfer the promise to the people as a whole. ${ }^{92}$ The application of this very phrase back again to the

above. As for the use of the word "remember", it is true that at Ps. 132:1 and Ne. 13:14 (inter alia) it is used in connection with an appeal to God to take note of someone's faithfulness, but that does not, of course, exclude its use of God making his promises effective; see W. Schottroff, 'Gedenken' im alten Orient und im alten Testament (2. Auflage. WMANT 15) Neukirchener Verlag, Neukirchen (1967) 199-217. Schottroff seems himself inclined to support the alternative understanding of 2 Ch. 6:42 (see pp.222-6), but is very hesitant about it, and certainly allows the possibility of the interpretation offered above.

${ }^{\prime \prime}$ W. A. M. Beuken, "Isa. 55, 3-5", argues against this parallel that "the connection with vss. $7 f$., where God praises David because of his 'good' intentions to build a house for Yhwh, has as much weight" (p.52). This seems less likely, however, because (i) verses $7 f$. are not part of Solomon's prayer, which starts rather at verse 14; (ii) there is no evidence that good intentions could be described as ḩśdym. Ps. 132 would allow the possibility that David's care for the Ark might be involved, but that is not mentioned in verses $7 \mathrm{f}$.; (iii) the same passage goes on immediately to relate that David was unable to realise his good intention, but that God kept his promise to David in allowing his son Solomon to complete the task (verse 10). The emphasis of these verses, therefore, is similar to those at the start of Solomon's prayer, and so cannot support Beuken's case.

${ }^{92}$ P. Volz, Jesaia II (KAT) A. Deichert, Leipzig (1932) 139-43, and especially O. Eissfeldt, "The Promises of Grace to David in Isaiah 55:1-5" in B. W. Anderson and W. Harrelson (eds.) Israel's Prophetic Heritage, SCM Press, London (1962) 196-207. 
context of the Davidic dynasty must thus be seen as telling evidence against Rudolph's and Plöger's view that the Chronicler intended to move away from any kind of royalist hope.

On the other hand, the use of this verse at the conclusion of Solomon's prayer of dedication is also noteworthy. We have seen that one of the main conditions that he had to fulfil if the dynasty was to be established was the building of the temple. With that now accomplished, it becomes fully intelligible that he should request God to "remember (his) steadfast, sure love for David". The positioning of this verse thus helps to confirm our interpretation of the dynastic oracle offered above, and again tells heavily against the view that the promise is exhausted with the completion of the temple building. Rather, on this basis, the exact opposite seems to be the case.

Immediately after Solomon's prayer, the Chronicler departs from his Vorlage in 1 Kings by recording that

When Solomon had ended his prayer, fire came down from heaven and consumed the burnt offering and the sacrifices, and the glory of the Lord filled the temple.

This dramatically underlines God's willingness to answer Solomon's request (expressed more conventionally at $2 \mathrm{Ch}$. 7:12ff.) and suggests to the reader that he may henceforth expect the unconditional guarantee that a king will rule in Jerusalem. Three passages in his subsequent narrative demonstrate that this is, in fact, the case.

(2) 2 Chronicles $13: 5-8$. It is widely agreed that, without prejudice to the question of a source for the material in this chapter, the speech of Abijah in verses 5-12 coincides with, and hence reflects, the Chronicler's own viewpoint. The themes with which it deals are prominent concerns of his elsewhere, and it appears furthermore to be crucial to a correct understanding of his narrative structure..$^{93}$ As far as I am aware, only Caquot has challenged this consensus, ${ }^{94}$ but since he gives no reasons to support his assertion, whereas at the same time the implications of these verses conflict with the rather extreme view he wishes to present, we need not delay to consider his opinion in detail.

${ }^{93}$ See Israel in the Books of Chronicles 111-15, 122.

${ }^{94}$ A. Caquot, "Peut-on parler de messianisme . . .?" 119 
Two aspects of kingship as presented here call for comment. First, we find reference to a theme emphasized elsewhere in Chronicles, namely the description of "the kingdom of the Lord in the hand of the sons of David" (verse 8).This concept is also introduced (sometimes by way of a slight change from the Vorlage) at 1 Chronicles 17:14; 28:5; 29:11 and 23; and 2 Chronicles 9:8. Equally, it provides the conceptual background necessary to understand 1 Chronicles $10: 14 b$. In his speech, Abijah employs the expression to prove the senselessness of the rebellious Northerners trying to withstand Davidic rule. This implies that included in the Chronicler's understanding was the idea both that the kingdom of the Lord coincided with its expression in Israel on earth and that, naturally enough, being God's kingdom, it was permanent and indestructible. This leads directly to our second consideration, for it must inevitably be asked whether there is any guarantee that the Lord will continue to express his kingship through the Davidic house. Verse 5 supplies a clear answer:

Ought you not to know that the Lord God of Israel gave the kingship over Israel for ever to David and his sons ss $^{95}$ a covenant of salt?

That God could pass the kingship from one dynasty to another is made clear from the explicit reference to its transfer from Saul to David (1 Ch. 10:14), but already in 1 Chronicles 17:13 it was promised that this would not happen again, and the analogy of this promise with "a covenant of salt" in our passage is intended to confirm this stability, for whatever be the origins of the expression in ancient custom, its use elsewhere in the Bible (Nu. 18:19 and cf. Lv. 2:13) points clearly to its eternal significance. ${ }^{96}$ Thus, the collocation of these two aspects of the speech of Abijah shows that by his time the members of the Davidic family were unchangeably established as those through whom God had chosen to exercise his kingship.

${ }^{95}$ RSV: "with". As there is, in fact, no preposition, the translation above, representing an accusative of nearer definition, seems slightly to be preferred; see C. F. Keil ad loc.; W. Rudolph, Chronikbücher 236-7; S. Japhet, Ideology 452-4. Strictly speaking, the relationship between God and David is not here described as covenantal (though cf. $2 \mathrm{Ch}$. 21:7); the covenant of salt is used, rather, as an analogy.

${ }^{96}$ In addition to the standard Bible Dictionaries and Encyclopaedias, see H. C. Trumbull, Studies in Oriental Social Life Hodder and Stoughton, London (1895) 111-12; W. Rudolph, Chronikbücher 237; S. Japhet, Ideology 452-4. 
(3) 2 Chronicles 21:7 - Yet the Lord would not destroy the house of David, because of the covenant which he had made with David, and since he had promised to give a lamp to him and to his sons for ever.

Two apparently ${ }^{97}$ significant changes distinguish this verse from its Vorlage in 2 Kings 8:19. First, the Chronicler has altered a reference to "Judah" to "the house of David" as that which the Lord did not want to destroy; secondly, while Kings says simply "for the sake of David his servant", Chronicles introduces "the covenant which he had made with David".

In this editorial passage, the Chronicler adopts the negative assessment of Kings on Jehoram, the king in question.

Nevertheless, even in such a case, the Chronicler strengthens the allusion to the unconditional promise to the Davidic dynasty, ${ }^{98}$ thus supporting once more our overall understanding of his position. Japhet argues that the importance of this verse within the book as a whole is quite secondary. ${ }^{99}$ It is true that it is based upon the account in Kings, but the fact that the Chronicler altered the text precisely, as we understand it, to heighten its force would suggest that he did not take it over mechanically, but because it suited his purpose to include it at this point.

(4) 2 Chronicles 23:3. For the story of the initiative of Jehoiada the high priest in overthrowing Queen Athaliah and restoring Joash, the sole survivor of the Davidic house, to the throne in Jerusalem, the Chronicler clearly bases himself squarely on the account in 2 Kings 11 . There are, however, more than the usual number of additions and omissions,

${ }^{97}$ In cases of small variations between Kings and Chronicles, it is acknowledged that the variation may not in every case be due to the Chronicler himself, but that his text of Kings may have already existed in a form different from that of the MT; see W. E. Lemke, "The Synoptic Problem in the Chronicler's History". In the present instance, however, the only alternative published witness which might indicate such a situation in fact supports the MT of Kings and Chronicles respectively in the matters with which we are concerned, while at the same time the alterations are in such accord with the Chronicler's outlook generally that attribution of the change to him remains the most probable explanation.

${ }^{98}$ Nor should it be forgotten that he also adopts the second half of the verse unchanged, and that it has the same point as its emphasis. Unfortunately, it is not fully clear what is meant by "a lamp", nor that the Chronicler necessarily understood it in the same way as Kings. For a number of suggestions, see the references in P. D. Hanson HTR 61 (1968) 297-320.

${ }^{99} \mathrm{~S}$. Japhet, Ideology 454-6. It is possible, however, that she is correct in detecting the influence of the Chronicler's doctrine of individual retribution on the change of "Judah" to "the house of David". 
suggesting that it is likely to be his own hand that lies behind the changes rather than more mechanical textual considerations. In 23:3, therefore, it is of interest to note an addition in line with the evidence we have already accumulated. When Jehoiada presents Joash as the king's son, the Chronicler adds, "Let him reign, as the Lord spoke concerning the sons of David". The reference to God's promise to David, established by Solomon as unconditional, is unmistakable.

In concluding this section, it is of interest to note the variety of situations that lies behind the last three passages we have discussed. The first was related to Abijah, of whom the Chronicler evidently approves, the second to Jehoram, of whom he has not a good word to say, and the third to a period when the dynasty as a whole came as close as imaginable to total destruction. It is admitted that by and large the allusions are brief, and that apparently not a great deal is made of them. Nevertheless, it may be asked whether it is not significant that, having established his position through his account of the united monarchy, the occasions on which he chooses to remind his readers of this theme are illustrative of the three major situations through which the dynasty could pass whilst remaining intact.

\section{The Significance of 2 Chronicles 7:12-22}

Our examination of the Chronicler's attitude towards the Davidic dynasty has attempted to show that in his opinion the promise to David, confirmed by Solomon's obedience, was of eternal validity. One objection to this understanding remains to be considered, and that is: is it at all probable that anyone living in Jerusalem during, as we understand it, the relatively stable period of Persian rule, a long period during which there was no Davidic king, nor any likelihood of one being enthroned, could have conceivably even dared hope that a descendant of David would ever again emerge as ruler? The analysis of one final passage, 2 Chronicles 7:12-22, may help to resolve this dilemma.

We have already had occasion to stress the importance for the Chronicler of Solomon's completion of the temple and his prayer at its dedication. We would thus expect 2 Chronicles 
7:12-22, which contains God's answer to that prayer, to be equally significant in the presentation of his theological position. Its main aim is to show that God has answered Solomon's prayer by "choosing" the new sanctuary, this being also the aim of 1 Kings 9:3-9, on which the Chronicler has based his account. He has also, however, adapted his Vorlage along characteristic lines.

The first major section, verses $13-15$, is completely additional to Kings. It relates to the people as a whole, and although it has generally been passed over very briefly by the commentators, yet it is in fact crucial for his well known doctrine of immediate retribution. This is a dogma of his that is always referred to, but has not, in my opinion, been analysed in anything like the detail it deserves. ${ }^{100}$ Such an analysis would take us beyond our present subject, but 7:14 would be central to it. In this verse, the Chronicler gives four possible responses of the people to imminent or actual disaster on the basis of which God will intervene with forgiveness and restoration. These four words are then each used in the subsequent narrative as markers at one point or another to introduce one of the miraculous interventions that are such a characteristic feature of the Chronicler's work. For instance, the verse starts, "If my people ... humble themselves ...". The first king after Solomon, Rehoboam, faced an invasion by Shishak, king of Egypt, in the fifth year of his reign (2Ch.12:1-12). Urged by the prophet Shemaiah, however,

the princes of Israel and the king humbled themselves and said "The Lord is righteous". When the Lord saw that they humbled themselves, the word of the Lord came to Shemaiah: "They have humbled themselves; I will not destroy them, but I will grant them some deliverance, and my wrath shall not be poured out upon Jerusalem ..." (verses 6-7).

${ }^{100}$ The basic examples have often been set out, e.g. by J. Wellhausen, Prolegomena zur Geschichte Israels (6th edition) Georg Reimer, Berlin (1905) 198-205 (E. T., Prolegomena to the History of Israel, A. and C. Black, Edinburgh (1885) 203-10); G. von Rad, Theologie I 345-7. Von Rad here also makes a better attempt than most to appreciate the theological significance of this doctrine, as also does S. Japhet, Ideology 159-208, but neither deals with the particular passage under analysis above. 
Similarly, of Rehoboam, it is said,

When he humbled himself the wrath of the Lord turned

from him, so as not to make a complete destruction (verse

12).

This word is used in a comparable way at 2 Chronicles 30:11; $32: 26 ; 33: 12,19,23 ; 34: 7$ and 36:12. Remarkably, however, though it is used on three occasions in the earlier narrative (1 Ch. 17:10; 18:1 and 20:4), these are all quite neutral theologically, and do not mark similar miraculous turning points. When it is now added that precisely the same situation holds for the other three programmatic words of 2 Chronicles $7: 14$ without a single exception, ${ }^{101}$ it will be apparent that the Chronicler intends us to understand God's answer to Solomon's prayer as both literal and as in some way initiating a new phase in God's relationship with his people. ${ }^{102}$ It is equally apparent that, as far as this promise goes, since we can check his attitude from his subsequent narrative, he was of the opinion that no external circumstances were too formidable to prevent God's immediate, direct and, if need be, miraculous move to fulfil it.

With this in mind, we turn to the second part of God's answer to Solomon, 2 Chronicles 7:17-18. Just as the first part dealt with Solomon's request for his people, so this one deals with his request concerning the status of the king, which we have already noted is intensified over against 1 Kings 6 . We have also seen the general importance that these verses have in the Chronicler's interpretation of the dynastic oracle. In the light of these factors, two slight changes that the Chronicler introduces here are to be regarded as significant. If they were quite isolated, we would probably agree with those who

10. (a) For "to pray", cf. 2 Ch. 32:20, 24 and 33:13, but contrast the "neutral" use at 1 Ch. 17:25 and 2 Ch. 7:1. (b) For "to seek (my face)", cf. 2 Ch. 11:16; 15:4, 15; $20: 4$, and contrast 1 Ch. $4: 39 ; 14: 8 ; 16: 10,11 ; 21: 3$. (c) "To return" is used frequently, but with theological significance of the sort referred to here only at $2 \mathrm{Ch}$. $15: 4 ; 30: 6,9$ and $36: 13$. It is true that the words "to pray" and "to return" occur a number of times in Solomon's prayer, 2 Ch. 6. However, since $2 \mathrm{Ch} .7: 14$ is the direct answer to that prayer, this fact would seem to strengthen, not undermine, our present contention.

${ }^{102}$ It is not suggested that $2 \mathrm{Ch} .7: 14$ contains the only words that have this kind of significance in Chronicles. There are several others, some of which seem to be based in a comparable way on $1 \mathrm{Ch} .10: 13-14$. Nevertheless, the facts set out above and in the previous note are too striking to be coincidental. 
regard them as trivial at best, ${ }^{103}$ but since they come in this passage whose careful construction is becoming apparent, I am now of the opinion that we should not pass over them so lightly.

First, in verse 18 , the Chronicler appears to have strengthened the reference to a covenant with David, substituting kārattî $l^{e}$ for dibbartî ${ }^{c}$ al $(1 \mathrm{Ki} .9: 5)$. It is true that some have suggested mere textual confusion here, ${ }^{104}$ and it must be agreed that this remains a possibility. However, there is no versional or other evidence that I am aware of to support this conjecture, so that we ought first to reckon with the evidence as it stands.

Secondly, at the end of the same verse, "a man upon the throne of Israel" has become "a man to rule Israel", which, of course, is an exact echo of Micah 5:1 (Evv. 5:2). Though there is no evidence that this is to be understood in a technical messianic sense here, ${ }^{105}$ yet it points once more, as do the other considerations already adduced, to an emphasis upon the promise of an eternal dynasty, once Solomon has fulfilled the necessary conditions.

The last section of this passage, verses 19-22, has just one significant difference from its Vorlage for our purposes, for it omits from verse 19 the reference in 1 Kings 9:6 to the sons of Solomon. ${ }^{106} \mathrm{By}$ retaining the second person plural form of address, however, it must be taken, on the basis of the foregoing context, to refer to Solomon and the people rather than Solomon and his descendants. Just as in the previous two sections, the conditions for the blessing of people and king have been treated separately, as in the prayer, so here they are brought together at the point where there is a warning of the dangers of judgement that would follow disobedience.

However, we cannot help noticing that, although Solomon is included in the warning, and although the judgement explicitly covers matters already dealt with in God's answer to him (exile, loss of land and destruction of the temple), yet

${ }^{103}$ E.g. W. Rudolph, Chronikbücher 218; S. Japhet, Ideology 490.G. von Rad, Geschichtsbild 124, draws attention to the changes in his treatment of the Davidic covenant in Chronicles, but without regard to the immediate context of the verse.

${ }^{104}$ E.g. Curtis and Madsen, Chronicles 351.

${ }^{105}$ Contra J. M. Myers, II Chronicles 44.

${ }^{106}$ See above, n.81. Again, I know of no textual evidence to prevent us exploring the possibility that this is a deliberate omission by the Chronicler. 
there is no hint of any sort that the dynastic promise would lose its validity. Since the apostasy alluded to in verse 19 is as drastic as can be imagined, this fact would seem once again to underline the unconditional nature of the promise.

Certain conclusions may be drawn, therefore, from this analysis of 2 Chronicles 7:12-22. On the one hand, it is clear that the Chronicler's presentation is in part an encouragement to his readers so to return to God in self-humbling and prayer that he will again intervene in their own generation as he had so manifestly done in the past in similar circumstances. There is no suggestion here of satisfaction with the present, but rather every encouragement to look towards a dramatic transformation in the future.

Alongside this hope, towards the realization of which the people can contribute, stands the promise of a restoration of the Davidic dynasty. For this, however, there is no indication that anything can be done to speed its realization, for throughout the Chronicler's history the rigid application of the concept of retribution leads also towards what might loosely be termed a democratic ${ }^{107}$ outlook, in which the individual's personal responsibility is more marked over against the earlier literature. Although there are still occasions where the king's activity inevitably affects the wellbeing of his people (most notably in $2 \mathrm{Ch}$. 28), yet more normally the people's own share in responsibility is clearly set out (e.g. 2 Ch. 12:1, 6; 13:13-18; 15:2, but contrast with $16: 7-10,12 ; 20: 2-4,13-23 ; 36: 12-16$ etc. $)$. Nowhere, however, is the possibility envisaged that the people's faithfulness will affect the king for blessing.

\section{Conclusions}

The main conclusions of this lecture may now be presented in summary form:

(1) Despite the widespread influence of the approach to the Chronicler's work typified by Plöger's book, some scholars have nevertheless attempted to find in it a more positive attitude towards the future. However, the main arguments on which these studies were based have not been found entirely satisfactory.

${ }^{107}$ See T. Willi, Die Chronik als Auslegung 161. 
(2) By his interpretation of the united monarchy of David and Solomon, and his handling of the dynastic oracle in the light of this, the Chronicler showed that in his view with the death of Solomon that promise was established as unconditional. (3) A number of other texts, though not numerous, were sufficient to confirm that this remains his position throughout the work.

(4) His doctrine of immediate and individual retribution, including as it does a firm belief in God's direct involvement in history, suggests both that the people themselves should be encouraged to look to the future for improvement in their present sorry condition, and that it is by no means absurd to maintain that the Chronicler could have inherited and passed on a continuing tradition of hope centred on the Davidic family. We have found no evidence that this is "messianic" in the strict sense (we prefer in consequence the expression "royalist"), nor do we wish to deny that with regard to some other prophetic hopes he may have presented a realized or inaugurated eschatology. ${ }^{108}$ This is not the same, however, as asserting that he was closed to the future; on the contrary, it would appear that he too was one who would have heartily endorsed the words of Jehoshaphat which he cites:

Hear me, Judah and inhabitants of Jerusalem! Believe in the Lord your God, and you will be established; believe his prophets, and you will succeed ( $2 \mathrm{Ch}$. 20:20).

${ }^{108}$ For an attempt to support this position in connection with the prophecies of the reunificationof Israel and Judah, see Israel in the Books of Chronicles 125-6. 